\title{
VIEW ON MALAYSIAN LAW OF YOUTH DEVELOPMENT
}

Asmah Laili Yeon, School of Law, UUM COLGIS,

Universiti Utara Malaysia, Malaysia.

E-mail: asmah485@uum.edu.my

Zainal Amin Ayub, School of Law, UUM COLGIS,

Universiti Utara Malaysia, Malaysia.

E-mail: z.amin@uum.edu.my

Alias Azhar, School of Law, UUM COLGIS,

Universiti Utara Malaysia, Malaysia.

E-mail: az.alias@uum.edu.my

Siti Alida John Abdullah, School of Government,

UUM COLGIS, Universiti Utara Malaysia,

Malaysia.E-mail: alida@uum.edu.my

Rozita Arshad, School of Government,

UUM COLGIS, Universiti Utara Malaysia, Malaysia.

E-mail: roz@uum.edu.my

Abstract: $49 \%$ of the total numbers of citizens of Malaysia are under the category of youth which is equivalent to 13.74 million people. Therefore, their contribution to the nation in education, economy, politics, social and governance are very significant. There is dilemma in defining legal age of youth not only in Malaysia but in global scenario, the issue of their awareness in youth development law and youth legal rights which are not documented in the statute. In light of the above gap, this paper examines and analyses legal challenges of current and future challenges of youth development law in Malaysia. This study adopts two approaches i.e. quantitative and qualitative approaches. For quantitative approach, an exploratory (sociolegal) survey technique using questionnaire has been conducted among youth in Malaysia to investigate their awareness in relations to law of youth development. The descriptive analysis is to describe level of youth awareness in relation to youth development law and the analytical analysis is to investigate deeply, and evaluate every aspect of legal provisions with regard to youth law. It is suggested that the Malaysian government should amend the definition of youth 
according to the international standard, initiate more programmes to increase the awareness of youth regarding the law and give a consideration to insert provision of youth rights in the Act.

Keywords: Youth, Youth law, Youth rights, Youth definition.

\section{INTRODUCTION}

In 2013, 49\% of the total numbers of citizens of Malaysia are under the category of youth which is equivalent to 13.74 million peoples. The youth age group between 20-24 years old (2.9 million) are the majority in numbers compared to other youth age group. However, the total numbers of youth involvement in youth societies or organization is only 23\% or 3,157,900 million (Ministry of Youth and Sports, 2015).

In Malaysia, the principle law governing activities and development of youth is the Youth Societies and Youth Development Act 2007 (YSYDA 2007). The Act defined youth as a person not less than 15 years and not more than 40 years old. The objective of the Act is to register youth societies, promote and facilitate the development of youth in Malaysia from the aspect of education, research and human resource, to establish a National Youth Consultative Council, to establish the Malaysian Institute for Research in Youth Development and to provide for related matters (Preamble of the Act 2007). There is dilemma in defining legal age of youth not only in Malaysia but in global scenario, the issue of youth awareness of youth development law and also youth rights which are not documented in the statute. In light of the above gap, this paper examines and analyses legal challenges of current and future challenges of youth development law in Malaysia.

\section{RESEARCH METHODOLOGY}

This study is a socio-legal study. Socio-legal study is a research method that brings together two major fields of research in the social sciences and the field of law. Both of these areas are equally 
important because it examines the relationship between law and society. According to Rohani Abdul Rahim (2002), law and society are closely related and difficult to be separated from each other. According to Zahra (1998), legal research is a systematic method of exploring, investigating, analyzing and conceptualizing legal issues pertaining to the enforcement mechanisms and implication of the legal rules and principles. Therefore, this research is a fresh, diligent, systematic, inquiry or investigation of the factual data and theoretical concepts of the rules and principles of youth law.

This study also will adopt two approaches i.e. quantitative and qualitative approaches. For quantitative approach, an exploratory (socio-legal) survey technique using questionnaire has been conducted among youth in Malaysia to investigate their awareness in relations to law of youth development. 267 youths has responded to the survey done by researchers during the State of Kedah Youth Day 2014, National Youth Day Celebration 2014 at Kuala Lumpur and Youth Volunteers Carnival 2014 Putrajaya. For the qualitative approach, the researchers refer to the statutes and decided cases.

The descriptive analysis is carried out with the purpose of stating the rules and principles of the law regarding youth. The purpose of analytical analysis is to investigate deeply, and evaluate every aspect of the factual data in the study. This is important because the researchers can criticize, revise and suggest or propose amendments mechanisms to the rules and regulations and the law relating youth. Primary data from survey was analysed using SPSS version 17 and descriptive statistic was used by the researcher in getting data on frequencies, means and standard deviation.

\section{LEGAL ISSUES OF CONCERNING YOUTH DEVELOPMENT}

\section{Definition of Youth}

In Malaysia, the principle law governing activities and development of youth is the Youth Societies and Youth Development Act 2007 (YSYDA 2007). The Act defined youth as a person not less than 15 years and not more than 40 years old. The first legal issue concerning 
the law of youth in Malaysia is concerning the definition of youth itself. As mentioned above, youth is defined as a person not less than 15 years and not more than 40 years old. According to the Age of Majority Act 1971 (AMA 1971), section 2 stated that the minority of all males and females shall cease and determine within Malaysia at the age of 18 years and every such male and female attaining that age shall be of the age of majority. It means at the age of eighteen years old, all citizen of Malaysia is considered as adult and they can enter into a legal contract or dealing with any third party but age limitation is not applicable to the following matters namely, marriage, divorce, dower, adoption, religious and religious rites and usage and any provision in any written law contained fixing the age of majority for the specific purpose of that written law (section 4, AMA 1971).

Thus, the YSYDA 2007 is not in conflict with age limitation provided under the AMA 1971 but according to the United Nation, youth is defined as those between the ages of 15 to 24 years old. Whereas, the Commonwealth defined youth as those between 15 to 29 years old and in the context Indian and African countries, youth is defined as those between 15 to 35 years old (Robertson and Jones, 2013). In Malaysia, the Youth Society and Youth Development Act 2007 (YSYDA 2007), youth is defined as any person between the ages of 15 and 40 years old. Currently, in March 2015, the Malaysian Youth Policy defined youth as those between 15 to 30 years old. However, the provision in the statute has yet to be amended. Only in Malaysia, the age range has been increased up to 40 years old. It is stated by the Commonwealth (2013) where youth development is referring to enhancing the status of young people and empowering them to build on their competencies and capabilities for life. It will enable them to contribute and benefit from a politically stable, economically viable, and legally supportive environment, ensuring their full participation as active citizens in their countries. It seems to be in Malaysia, the broad definition of youth age includes a large segment of population with different interests, attitudes, needs, skills, education etc. Therefore, it is difficult for the government and related agencies to plan activities and programmes that is suitable to all age group of youth. 
In the case of Calalang v William G.R. No. 47800. December 2, 1940, Justice Laurel defines social justice as "the promotion of social justice is to be achieved not through a mistaken sympathy towards any given group.... it means the promotion of the welfare of all people, the adoption of the Government measures calculated to ensure economic stability of all the competent elements of society, through the maintenance of a proper economic and social equilibrium in the interrelations of members of the community, constitutionally through the adoption of measures legally justifiable.....". Therefore in designing the policy or law in relations to youth development it must be in line with the philosophy of social justice and equality before the law amongst categories of citizenship in Malaysia.

If we analyse the policy and law of youth development, it seems to be in order but in terms of implementation of activities or programmes it will be imbalance if the planning is not proper. For example the age gap of the so-called youth is so wide ( 15 years old up to 40 years old) resulting in over generalization of programmes and activities for the group as a whole.

\section{Youth Rights}

According to the Commonwealth Youth Development Index (YDI), youth development enhances the status of young people, empowering them to build on their competencies and capabilities for life. It will enable them to contribute to and benefit from politically stable, economically viable and legally supportive environment, ensuring their full participation as active citizens in their countries. Therefore, there are five domains which is used to measure youth development which is closely related to their rights i.e. education, health and wellbeing, employment, political participation and civic participation. The five domains used are quite similar to the Malaysian Youth Policy as stated in the YSYDA 2007. Under the YSYDA 2007, it is stated in section 34 of the Act that the policies or directives be made by the Minister of Youth and Sports relating to youth developments are for the following purposes; (a) youth knowledge development, (b) youth attitude development, (c) youth leadership and organisational development, (d) youth vocational and 
entrepreneurial development, (e) inculcation of a healthy lifestyle in the youth, (f) facilities for social interaction for the youth, (g) youth partnership in development and (h) international relations and networking amongst the youth.

What is the scenario in Malaysia and to what extent youth rights and protection is legally recognised? The YSYDA 2007 do not include specific provisions on youth rights, however, in general the Federal Constitution of Malaysia (FC) recognized the equality and justice principle among citizens of Malaysia. This is based on article 8 of the FC. Further, right of education and property also is provided under the FC. Even though the prohibition of slavery and forced labour is prohibited under article 6 of FC, in the case of employment law, there seems to be a vacuum in terms of protection in law for students of higher education when they undergo their attachment programme with the industry for a period of time e.g. 2 to 6 months. Similarly, with any youth undergo the internship programme which is less than 2 years tenure. The law does not protect the welfare of trainees or apprentice because provision of allowances, insurance protection, protection from manipulation and discrimination is not provided under the Act etc. (Employment Act 1955). Under section 2 of the Employment Act 1955, the apprenticeship contract means a written contract entered into by a person with an employer who undertakes to employ the person and train or have him trained systematically for a trade for a specified period which shall not be less than two years in the course of which the apprentice is bound to work in the employer's service.

The discussion below will be based on the findings of research concerning youth perspective on youth rights in Malaysia. Youth rights is referring to right to survival, right to develop to the fullest, right to protection from harmful influences, abuse and exploitation and right to participate fully in family, cultural and social life.

The respondents were asked whether youth rights should be incorporated in the YSYDA 2007. Table 1 shows that $61.1 \%$ agree youth rights should be incorporated in the statute and only $38.9 \%$ of respondents disagree with the suggestion. 
Table 1: Youth Rights Should Be Incorporated in the YSYDA 2007 With reference to youth rights to survival which include basic rights to live, employment, health and wellbeing and etc, Table 2 below shows that $74.9 \%$ agree with the items. Surprisingly, $25.1 \%$ disagree that these items should be included as rights of youth.

\begin{tabular}{|c|c|c|}
\hline & Frequency & Percent \\
\hline Strongly disagree & 7 & 2.6 \\
\hline Disagree & 13 & 4.9 \\
\hline Not sure & 84 & 31.5 \\
\hline Agree & 96 & 36.0 \\
\hline Strongly Agree & 67 & 25.1 \\
\hline \multirow[t]{3}{*}{ Total } & 267 & 100.0 \\
\hline & & Std Deviation .971 \\
\hline & & Mean \\
\hline
\end{tabular}

Table 2: Right to Survival

\begin{tabular}{lcc}
\hline & Frequency & Percent \\
\hline Strongly disagree & 9 & 3.4 \\
Disagree & 9 & 3.4 \\
Not sure & 49 & 18.4 \\
Agree & 113 & 42.3 \\
Strongly Agree & 87 & 32.6 \\
Total & 267 & 100.0 \\
& \multicolumn{2}{c}{ Std Deviation .975} \\
& \multicolumn{2}{c}{ Mean } \\
\hline
\end{tabular}

Further, Table 3 below shows that $77.2 \%$ respondents agree with the right of youth to develop have been given the fullest according to the existing law. This include (a) youth knowledge development, (b) youth attitude development, (c) youth leadership and organizational development, (d) youth vocational and entrepreneurial development, (e) inculcation of a healthy lifestyle in the youth, (f) facilities for social interaction for the youth, (g) youth partnership in development and (h) international relations and networking amongst the youth. However, $22.8 \%$ of respondents disagree with the statements. 
UUMJLS 7, 71-82 (2016)

Table 3: Rights to Develop to the Fullest

\begin{tabular}{lcc}
\hline Valid & Frequency & Percent \\
\hline Strongly disagree & 9 & 3.4 \\
Disagree & 8 & 3.0 \\
Not sure & 44 & 16.5 \\
Agree & 123 & 46.1 \\
Strongly Agree & 83 & 31.1 \\
Total & 267 & 100.0 \\
& & Std Deviation .950 \\
& & Mean \\
\hline
\end{tabular}

Table 4 shows the response from respondents concerning rights to protection from harmful influences, abuses and exploitation where $73.4 \%$ of respondents agree with these rights but $26.6 \%$ disagree with the right.

Table 4: Rights to Protection from Harmful Influences, Abuses and Exploitation

\begin{tabular}{lcc}
\hline Valid & Frequency & Percent \\
\hline Strongly disagree & 7 & 2.6 \\
Disagree & 10 & 3.7 \\
Not sure & 54 & 20.2 \\
Agree & 89 & 33.3 \\
Strongly Agree & 107 & 40.1 \\
Total & 267 & 100.0 \\
& & Std Deviation .995 \\
& & Mean \\
\hline
\end{tabular}

Table 5: Right to Participate Fully In Family, Cultural and Social Life

\begin{tabular}{|c|c|c|}
\hline Valid & Frequency & Percent \\
\hline Strongly disagree & 7 & 2.6 \\
\hline Disagree & 10 & 3.7 \\
\hline Not sure & 54 & 20.2 \\
\hline Agree & 89 & 33.3 \\
\hline Strongly Agree & 107 & 40.1 \\
\hline \multirow[t]{3}{*}{ Total } & 267 & 100.0 \\
\hline & & Std Deviation .995 \\
\hline & & Mean $\quad 4.04$ \\
\hline
\end{tabular}


Majority of respondents (73.4\%) agree that the law should include the right to participate in family, cultural and social life. This shows that youth are very much interested to participate in activities not only within their family ties but in community at large.

\section{Youth awareness on the Policy of Youth Development}

Under section 55 of the YSYDA 2007, one of the functions of Malaysian Institute for Research in Youth Development, Ministry of Youth and Sports is to carry out educational and awareness programmes for the promotion of youth development. However, to what extent the Ministry plays its role to inculcate knowledge of law to youths in Malaysia. The finding shows that $66.6 \%$ agree that they know about youth law through their involvement in Ministry of Youth and Sports activities. 72.3\% through their involvement in youth society activities, $69.3 \%$ from mass media and $56.9 \%$ from formal education. Therefore, it is important that the Institute under the ministry to upgrade their effort in dissemination of knowledge of youth development law.

In relation to the knowledge of youth on the eight main policies regarding youth development, the overall findings shows that less than $60 \%$ of respondents are fully aware about these eight main policies which signifies the main responsibilities of the Ministry of Youth and Sports and other related ministries in Malaysia in managing youth affairs. Therefore, researchers are of opinion dissemination of information among youth should be enhanced in order to update them with relevant information about law and regulations.

\section{CONCLUSION}

As said by Mr Robinson, the Head of Youth Programme of the Commonwealth Secretariat (2015), Malaysia is one of the country in Commonwealth has acknowledge and recognized the contribution of youth by having a legal documentation and policy for youth and it also practice a good governance in managing youth affairs. He is also agreed with the suggestion that youth rights should be included 
in the statute. This is to encourage the ministries to speed up their action to provide the fullest protection to youth. The researchers are of opinion that there are some improvements should be executed by the Ministry of Youth and Sports and other ministries which are responsible to youth development in Malaysia. Protection of law should be given to youth especially those who are in the internship programme which is less than 2 years. They should be given some protection and benefits as employee since they are working for the institution/company during the period of internship. The internship agreement between youth and employer should secure rights and responsibilities of both parties and it should be recognized under the employment laws.

Further, from the finding of research concerning youth perspective on whether youth rights should be incorporated in the statute, majority of respondents among youth agree with the suggestions. Looking at this scenario it is suggested that provisions of youth rights should be incorporated in the YSYDA 2007 as a guideline to the government ministries and agencies to give greater protection and security to youth. Further, as to the question of age of youth, the researcher would suggest youth in Malaysia is to be defined as a person who is within the age of 18 to 30 years old. It is easier for the government or agencies or organizations to plan a good and quality activities for the best interest of youth citizens in Malaysia. The researchers also would suggest that the ministries should disseminate more information about law and regulation to youth because less than $60 \%$ of respondents are fully aware about these eight main policies of youth in Malaysia.

As a conclusion, the youth of Malaysia have an important role to play in helping the government to achieve the status of a fully developed country by the year 2020. The Malaysian vision 2020 aims to develop all aspects of the country including national unity, social cohesion, economy, social justice, political stability, system of government, quality of life, social and spiritual values and national pride and confidence. Therefore, all relevant and material information should be disseminated to all youth in Malaysia so that they can participate and contribute to the nation and be smart 
partners to the government ministries. Their rights and protection should be recognized by the government by acknowledging it with legal recognition.

\section{Acknowledgements}

The authors wish to thank the Ministry of Education Malaysia for funding this study under Niche Research Grant Scheme.

\section{REFERENCES}

ILBS. (2007). Youth Societies and Youth Developments Act, Kuala Lumpur: ILBS Publications.

ILBS. (2007). Age of Majority Act 1971. Kuala Lumpur: ILBS Publications

ILBS. (1955). Employment Act 1955. Kuala Lumpur: ILBS Publications.

Calalang v William G.R. No. 47800. December 2, 1940, see http:// elaw.i.ph/blogs/elaw/2008/09/09/calalang.vs-williamsconstitutional-law-digest/ (9 Sept 2009)

EKCYP. (2012). Europe: Knowledge. European Knowledge Centre for Youth Policy (EKCYP) access atwww.youth-partnership. net/youth-partnership/ekcyp/index

Pittman, K. J., Ray O., \& Mary K. (1993) Youth Development and Resiliency Research: Making Connections to Substance Abuse Prevention. New York: Center for Youth Development and Policy Research/Academy for Educational Development.

Robertson A., \& Jones-Parry R. (2013). The Commonwealth Yearbook 2013. Commonwealth Secretariat by Nexus Strategic Partnerships); (eds) (2013) and Cambridge: Nexus/ Commonwealth Secretariat.

Robinson, L. (2015). An Interview conducted by researchers at his office in London, January 2015. The commonwealth Secretariat on Youth Programme.

Rohani Abdul Rahim. (2002). Metodologi Penyelidikan Undangundang: Satu tinjauan kepada kajian sosio-perundangan. Kertas kerja seminar Kemantapan Akademik UKM. 
Mahdi Zahra. (1998). Research Methods for Law Postgraduate. Kuala Lumpur: Stilglow Sdn. Bhd

Ministry of Youth. (2015). Interview with the Deputy Director of Policy and Governance Department, Ministry of Youth and Sports. May 2015.

The Commonwealth. (2013). Youth Development Index. Results Report. September 2013. 